\title{
EKSISTENSI BATA KUNO DI MUSEUM BENTENG SOMBA OPU MEMBERI SUATU MAKNA
}

\author{
Meanings of Ancient Brick in Somba Opu Fortress
}

\author{
Muhaeminah \\ Balai Arkeologi Makassar \\ Jl Pajjaiyang No. 113, Sudiang Raya, Makassar \\ Email: minbalar@gmail.com
}

Naskah diterima tanggal 27 Juni 2014. Naskah direvisi tanggal 18 Agustus 2014. Naskah disetujui tanggal 25 Agustus 2014.

\begin{abstract}
Abstrak
Penelitian ini bertujuan untuk mengungkap data sejarah arkeologi benteng Somba Opu kabupaten Gowa, dengan menggunakan metode pengamatan terhadap keterkaitan data dengan keberadaan benteng. Survei dan wawancara dengan tokoh masyarakat setempat guna memperoleh gambaran stori situs benteng Somba Opu. Test-pit, yang dilakukan untuk mengetahui berbagai bentuk peninggalan arkeologi yang terdapat di dalam tanah dengan membuka kotak galian 100x100 cm dengan pendalaman menggunakan sistem spit dengan ukuran kedalaman yang ditetapkan $15 \mathrm{~cm}$ secara konsisten setiap spitnya. Hasil penelitian, membuktikan bahwa nilai historisnya sangat tinggi, sehingga dalam proses kolonialisasi diawali dengan kegiatan perdagangan, penguasaan ekonomi, kemudian meningkat menjadi penguasaan dibidang politik, dengan penguasaan inilah maka terjadi suatu hubungan yang tidak harmonis antara kerajaan Gowa dengan kolonial Belanda, dan akhirnya disepakati suatu perjanjian yaitu Perjanjian Bungaya maka Benteng Somba Opu sebagai kejayaan Gowa dihancurkan dan diratakan dengan tanah oleh penjajah Belanda. Tinggalan arkeologi berupa fragmen bata yang masih jelas goresan huruf lontara jangang-jangang, bekas kaki binatang, perahu dan motif tikar.
\end{abstract}

Kata kunci: arkeologi, sejarah, benteng, bata, kerajaan

\begin{abstract}
Research aimed to reveal archeological history of Somba Opu fortress. Survey and interview was performed with local community to get a data on Somba Opu fortress. Test-pit was performed during the research to reveal some of archeological relics buried in soil. It was dug out $100 \times 100 \mathrm{~cm}$ with the depth of $15 \mathrm{~cm}$ to each spit consistently. Research shows that the brick has great meanings. In colonization era, the disharmonious relation between Gowa kingdom and the Ducth has led to the Bungaya agreement. Sombo opu Fortress then destroyed by the Dutch and left only the bricks. Some of the bricks shows characters of lontara jangangjangang, trace of animal feet, and plaited mat.
\end{abstract}

Keywords: archeology, history, fortress, bricks

\section{PENDAHULUAN}

$\mathrm{M}$ anusia adalah makhluk yang memiliki kemampuan, dengan akal dan budi manusia mampu melaksanakan tindakantindakan untuk memenuhi kebutuhannya dan dengan akal budi pula manusia menciptakan kebudayaan (Bernadeta, 2009: 11). Artefak pada dasarnya memiliki tiga macam fungsi, yaitu teknofak, sosiofak, maupun ideofak. Pada kenyataannya fungsi-fungsi tersebut dapat diketahui dengan melihat konteksnya (Binford, 1965: 217225). Bata sebagai salah satu jenis artefak yang memiliki fungsi utama yang bersifat teknis (artefak teknomik) sebagai bahan penyusun bangunan secara permanen. Akan tetapi manakala pada bata tersebut terdapat beberapa hiasan karena perilaku manusia, maka akan timbul tafsiran makna yang bermacammacam. Makna suatu benda atau artefak tertentu dapat diketahui dengan menghubungkan maksud dan tujuan serta pemanfaatannya oleh pengguna. Sehingga bata-bata dari benteng Somba Opu 
terbukti mengandung makna hiasan dengan bentuk dan motif yang bermacam-macam, demikian pula dalam teknik pengerjaannya.

Dalam tulisan ini penulis mengungkap beberapa hal yang melatar belakangi adanya batabata berhias dari benteng Somba Opu. Bata salah satu jenis benda arkeologi dari situs benteng Somba Opu yang menjadi koleksi Museum Karaeng Pattingalloang yang terletak di situs benteng Somba Opu, Kec. Pallangga, Kab. Gowa, Provinsi Sulawesi Selatan. Diberi nama Museum Karaeng Pattingalloang karena Karaeng Pattingalloang adalah bangsawan Kerajaan Tallo yang pernah menjabat Mangkubumi pada masa pemerintahan Sultan Malikussaid (Raja Gowa XV), Karaeng Pattingalloang adalah seorang yang pernah menjadi pengusaha Internasional Bersama Sultan Malikussaid (Poelinggomang, 2004: 29) Ia adalah seorang ahli hukum dan menguasai beberapa bahasa asing antara lain. Belanda, Denmark, Spanyol dan Cina, dari penghuni kota Makassar (Rosmawati, 2013).

Museum Karaeng Pattingalloang memiliki berbagai fragmen diantaranya meriam, peluru, mata tombak, paku, keramik, mata uang, fragmen tungku, dan mata kail. Dari temuan yang berbahan tanah liat selain bata berhias juga ditemukan berupa fragmen pedupaan, guci kecil, piring kecil yang merupakan alat upacara. Benda-benda alat rumah tangga antara lain berupa tempayan, batu asah, fragmen tungku, fragmen cetak kue, cobekan, belanga dan sebagainya. Reruntuhan dinding benteng ditemukan melalui ekskavasi yang dilakukan oleh Suaka Peninggalan Sejarah dan Purbakala, kemudian dilakukan ekskavasi oleh Mahasiswa UNHAS bekerjasama dengan mahasiswa Fakultas Adab IAIN Alauddin serta Tim dari Suaka PSP tahun 1987 dan kemudian oleh Proyek Miniatur Sulawesi Selatan pada tahun 1989 - 1990 (Darmawan, dkk. 1990).

Pada tahun 2013. Balai Arkeologi Makassar telah melakukan penelitian di Museum Karaeng Pattingalloang serta situs-situs arkeologi Islam di wilayah bekas kerajaan Gowa. Penelitian arkeologi tersebut difokuskan untuk pembuktian arkeologi tentang jejak-jejak arkeologi Islam serta toponimtoponim yang dikisahkan di dalam naskah-naskah lontara, misalnya pada lontara Gowa, lontara Bilang dan lontara Bugis. Penelitian awal telah menyentuh pada situs-situs yang berindikasi tinggalan kerajaan awal masa Islam di Katangka, Taeng, Barombong, Somba Opu (pesisir barat) dan Bungayya. Penelitian sesi dasar ini secara khusus melakukan identifikasi serta analisis awal terhadap situs-situs dan material tinggalan budaya yang ditemukan. Hasil identifikasi dan analisis telah melahirkan beberapa asumsiasumsi dasar dengan memberikan pemahaman yang berkaitan dengan masa awal keberadaan Islam sampai perkembangan kerajaan Gowa pada masa selanjutnya (Muhaeminah, 2013: 2).

Benteng Somba Opu merupakan bangunan dinding yang melindungi istana raja Gowa, Masjid, perkampungan dan petinggi kerajaan. Benteng Somba Opu adalah benteng induk yang melindungi benteng pengiring seperti Istana kerajaan Gowa, benteng Panakukang, benteng Ujung Pandang (Benteng Fort Rotterdam) dan benteng Garassi. Poelinggomang dalam bukunya menjelaskan bahwa, antara tahun 1550-1650 terdapat 8 kota yang dikategorikan ramai di Asia Tenggara. Salah satunya adalah kota Somba Opu atau Bandar Makassar Kota Somba Opu tak lain adalah Benteng Somba Opu serta kawasan sekitarnya. Benteng yang menghadap langsung ke Selat Makassar ini pada abad ke XVIXVII Masehi merupakan pusat kerajaan Gowa yang memperluas kekuasaannya dan termasuk menjalin hubungan kerjasama dan perjanjian dengan kerajaan lain (Poelinggomang, 2004: 30) sebagai kota pelabuhan perdagangan di kawasan timur Indonesia (Darmawan, dkk. 1992: 10-36). Melalui informasi tersebut di atas maka dapat diketahui bahwa Benteng Somba Opu memiliki nilai histori dan arkeologi yang penting dan menarik untuk diteliti.

\section{Tinjauan Pustaka}

Merujuk peta Bleau 1638 dapat digambarkan bahwa di dalam benteng Somba Opu terdapat istana raja (Balla Lompoa), rumah para elit kerajaan, dan rumah-rumah para bangsawan yang terlindung tembok tebal dan tinggi melingkar dengan pasilitas persenjataan memadai. Di dalam benteng Somba Opu terdapat jalan utama yang membujur utaraselatan membelah benteng menjadi dua bagian pada sisi jalan poros utama sebelah utara benteng dihuni para bangsawan, bersebelahan dengan pasar yang terletak di bagian dinding utara (Tim Penelitian Peradaban Gowa-Tallo Tahap I, 2007: 50).

Tahun 1669 Benteng dan istana Somba Opu diratakan dengan tanah oleh Belanda, demikianlah maka Makassar menjadi pusat pemerintahan dan perdagangan orang-orang Belanda, poros Somba Opu garis Makassar hilang. Tinggallah Makassar memasuki babak sejarah baru dan Somba Opu yang pernah menjadi pusat pemerintahan kerajaan Gowa tinggal menjadi puing-puing (Sumalyo, 2013: 47). 
Secara keseluruhan berdasarkan hasil ekskavasi diperoleh data ukuran bervariasi begitu pula beberapa batu bata besar berukuran panjang dan tebal. Nilai penting benteng Somba Opu inilah yang harus dilestarikan dan disajikan kepada masyarakat melalui keberadaan bukti-bukti fisik (tangible). Dengan demikian, masyarakat tidak hanya mendengar kisah tentang nilainilai pentingnya, tetapi juga dapat menyaksikan tinggalan-tinggalan sejarah dan budaya yang nyata tersebut. Sisa-sisa aktivitas kota Somba Opu telah diupayakan pengungkapannya sejak tahun 19831992 dalam rangkaian Proyek Miniatur Sulawesi Selatan. Sejumlah temuan penting hasil ekskavasi arkeologi sekarang disimpan di museum di dalam kompleks situs Somba Opu koleksi artefak yang ditampilkan sebagai gambaran aktivitas kota (abad ke-16-17 (Tim Penelitian pradaban Gowa Tallo tahap I, 2007: 50).

Nilai Penting Ilmu Pengetahuan. Benteng Somba Opu terbukti telah menumbuhkan minat bagi para ahli di bidang ilmu arkeologi dan sejarah. Minat ini ditunjukkan dari sejumlah penelitian yang sudah dilakukan oleh sejumlah sarjana dari dalam maupun luar negeri. Sejumlah tulisan ilmiah yang telah dihasilkan, diterbitkan, dan dibahas dalam berbagai forum ilmu pengetahuan di tingkat nasional dan internasional (Rustan, Iswadi dan Supriadi, 2013: 118).

\section{METODE PENELITIAN}

Metode yang digunakan dalam penelitian ini yaitu metode pengamatan terhadap keterkaitan data dengan keberadaan benteng. Survei dan wawancara dengan tokoh masyarakat setempat guna memperoleh gambaran stori situs benteng Somba Opu. Test-pit yang dilakukan untuk mengetahui berbagai bentuk peninggalan arkeologi yang terdapat di dalam tanah dengan membuka kotak galian 100x100 cm dengan pendalaman menggunakan sistem spit dengan ukuran kedalaman yang ditetapkan $15 \mathrm{~cm}$ secara konsisten setiap spitnya. Setelah mendeskripsikan data sejarah arkeologi benteng Somba Opu.

\section{PEMBAHASAN}

Benteng Somba Opu terletak di kampung Sapiria kelurahan Somba Opu, kecamatan Pallangga kabupaten Gowa namun seiring dengan pembangunan kota serta kebutuhan masyarakat untuk rekreasi, maka jalan masuk ke Benteng Somba Opu dibangun kembali dan terletak di jalan
Daeng Tata Makassar Provinsi Sulawesi Selatan. Benteng Somba Opu berjarak $25 \mathrm{~km}$ dari kota Makassar. Dari arah jalan Cendrawasih (sebagai pusat kota Makassar), perjalanan dapat ditempuh selama kurang lebih 15 menit dengan menggunakan kendaraan roda dua dan roda empat.

Kondisi wilayah situs mengacu pada peta topografi Situs Benteng Somba Opu terletak di daerah aliran sungai Je'ne Berang tepatnya diapit oleh dua sungai yang bermuara di sekitar Garassi. Melihat posisi situs diperkirakan pada masa lampau Sungai Je'ne berang ini merupakan salah satu sumber daya alam yang dimanfaatkan sebagai jalur pelayaran yang menghubungkan antara wilayah pantai dan pedalaman. Adanya jaringan air ini memberikan keleluasaan dalam kepentingan penguasa (raja) dengan rakyatnya, begitu juga masyarakat pendukung budaya mengadakan kontak dengan daerah luar, yang pada gilirannya memunculkan sistem ekonomi dan salah satu diantaranya adalah perdagangan, seperti diketahui munculnya aktifitas perdagangan yang disebabkan oleh adanya tuntutan terhadap kebutuhan keseharian manusia untuk hidup.

Sedangkan bata-bata kuno di museum benteng Somba Opu yaitu: pertama bata berhias yang ditemukan sebanyak 40 buah di antaranya motif aksara lontara jangang-jangang sebanyak 4 buah, motif kaki ayam sebanyak 3 buah, motif jarijari sebanyak 3 buah, motif perahu 3 buah, motif tikar 1 buah, motif flora 4 buah, motif naga 2 buah, motif ikan, motif kaki anjing 3 buah, motif kotika 3 buah, motif kaki kuda 1 buah, lingkaran bambu 1 buah, dan beberapa motif tidak teridentifikasi.

Kedua bata polos yang ditemukan sebanyak 14 buah. Adapun ukuran bata polos dan berhias memiliki beberapa variasi ukuran, dan temuan bata tersebut adalah merupakan koleksi museum Karaeng Pattingalloang, Benteng Somba Opu. Ukuran yang dapat diketahui, antara lain; panjang antara $23-31 \mathrm{~cm}$, lebar antara $13-18,5 \mathrm{~cm}$ dan tebal antara 2, 5-5 cm. Bata hasil temuan ekskavasi di benteng Somba Opu dianggap memiliki nilai penting maka hasil temuan ini disimpan di museum, karena museum berperan serta dalam upaya pembelajaran dan peningkatan apresiasi masyarakat terhadap warisan budaya guna memperkokoh jatidiri bangsa, dan meningkatkan kebanggaan nasional karena museum berfungsi sebagai tempat pelayanan informasi dalam berbagai aspek, termasuk sebagai wahana dalam kegiatan sosial (Depdikbud, 2006: 1). 


\section{Sejarah Singkat Benteng Somba Opu}

Benteng-benteng pertahanan adalah jenis tinggalan arkeologi yang banyak ditemukan di Sulawesi Selatan. Antara lain Benteng Tallo, Benteng Sanrobone, Benteng Rotterdam atau Benteng Pannyua (Benteng Ujung Pandang), dan Benteng Somba Opu. Benteng-benteng tersebut telah dihancurkan oleh Belanda kecuali benteng Ujung Pandang, sehingga tidak dapat lagi kita saksikan bentuk asli bangunannya (Muhaeminah, 2009: 51). Benteng Ujung Pandang kini dikenal sebagai Fort Rotterdam, yang merupakan Benteng pengawal dari Benteng Somba Opu (benteng induk). Benteng Ujung Pandang telah diubah arsitekturnya dengan gaya Eropa ketika Belanda masuk ke Sulawesi Selatan pada abad ke XVII Masehi dan diberi nama Fort Rotterdam seperti tertulis di pintu masuk Benteng.

Benteng Somba Opu adalah benteng kerajaan, yang dibangun oleh Sultan Gowa ke IX Daeng Matanre Karaeng Tumapảrisi Kallonna pada tahun 1525, kemudian dilanjutkan oleh raja Gowa ke XII Karaeng Tunijallo dan diberi batu bata oleh Sultan Alauddin kemudian disempurnakan dan dijadikan benteng induk serta pusat pemerintahan Kerajaan Gowa oleh Sultan Hasanuddin. Pada pertengahan abad ke XVI Masehi benteng ini menjadi pusat perdagangan dan pelabuhan rempah-rempah yang ramai dikunjungi pedagang asing dari Asia, Eropa, dan pernah menjadi Ibu kota pusat Kerajaan Gowa. Pusat kerajaan berada di bukit Tamalate, kemudian pada masa pemerintahan raja Gowa ke IX. Daeng Matanre karaeng To Mapa'risi Kallonna tahun 1510 Masehi beliau memindahkan pusat kerajaan ke Somba Opu, yang terletak pada delta Sungai Jeneberang. Benteng Somba Opu berkembang menjadi pusat pemukiman bahkan menjadi pusat kota dimana tidak hanya warga kekaraengan Gowa saja yang tinggal dan menetap disekitar benteng, tapi juga para pedagang dari segala penjuru dunia yaitu Denmark, Inggris, Portugis, Gujarat, yang memiliki kantor sendiri bagi kegiatan dagang mereka, di dekat benteng disediakan beberapa tempat yang berfungsi sebagai pasar, keramaian di muara Sungai Je'neberang di saat kapal-kapal sandar (Pradadimara, 2013: 33).

\section{Makna Bata dan Fungsinya Makna Hiasan Bata}

Masyarakat Bugis Makassar mengenal pola hias yang berasal dari alam, flora, dan fauna, meski dalam bentuk yang sederhana. Selain untuk keindahan, ada pola hias yang mengandung makna dalam kehidupan budayanya. Salah satunya ialah bunga parenreng, bunga melati. Tumbuhan ini menjalar tidak putus-putusnya, sehingga diumpamakan rezeki yang terus menerus. Pola hias ini biasanya tertera di timpa laja, induk tangga, atau papan pintu dan jendela.

Dari dunia fauna terdapat tiga bentuk ragam hias yang banyak dipakai yaitu kepala kerbau, ayam jantan, dan naga. Ayam jantan bagi masyarakat Bugis Makassar perlambang keberanian yang harus diteladani. Ukiran bermotif naga juga ditempatkan pada puncak bubungan atau induk tangga. Naga melambangkan kekuatan yang maha dahsyat. Dan menurut kepercayaan, bila sang naga murka akan menelan bulan dan matahari, sehingga terjadi gerhana. Karena itu memasang ornamen ini harus tepat arahnya (Soeroto, 2003: 125)

Bata Benteng Somba Opu memiliki motif garis dan pola hias, pola hias tertera dengan berbagai macam bentuk diantaranya adalah: motif gambar perahu, bekas kaki binatang (ayam dan anjing), ular naga, kotika, dan aksara jangangjangang. Penulis memberikan makna bahwa pola hias yang tertera pada bata benteng Somba Opu yang lama terpendam di dalam tanah memberi makna yang tidak jauh beda dengan makna yang biasa digunakan pada bangunan rumah raja orangorang Bugis Makassar yaitu adanya flora dan binatang. Makna flora memberikan suatu indikasi rezeki, kemudian binatang ayam (kaki ayam, kaki anjing) adalah perlambang keberanian. Pola hias naga adalah melambangkan kekuatan yang maha dahsyat. Aksara jangang-jangan adalah makna memohon kekuasaan Dewa, Aksara yang tertera sangat jelas artinya dalam bahasa Makassar.

Industri hiasan bata kuno benteng Somba Opu adalah bukan hanya sebagai penanda (merek) atau semacam stempel pada bata akan tetapi mempunyai makna tertentu pada saat itu, hanya pemasangan bata tidak teridentifikasi karena tidak sesuai pada tempatnya pada saat diekskavasi. Sebagaimana ditemukan pada bangunan rumah-rumah raja di Sulawesi Selatan, seperti pada bangunan saoraja Balla Lompoa Gowa. Ragam hias yang terpasang di puncak timpa laja atau timba sila atau disebut anjong bola (bahasa lokal).

Eksistensi bata kuno pola hias perahu juga digunakan sebagai sarana transportasi yang penting pada masa itu. Dalam sejarah dikisahkan bahwa mulai memuncaknya hubungan dagang dengan daerah luar tidak hanya melalui antar pulau, 
bahkan di antara pulau di Nusantara meliputi Jawa, Borneo/Kalimantan, Maluku, Malaka, Johor, dan Pahang (lihat lampiran foto 1 Motif Perahu). Makna lain pada bata yang bermotif perahu misalnya, merupakan satu sisi sosial tertentu yang sangat lekat dengan masyarakat Makassar pada saat itu, yakni tradisi kemaritiman. Dari bentuk perahu yang menggunakan layar menunjukkan informasi tersendiri tentang tingkat teknologi pembuatannya. Serta menunjukkan adanya kelompok sosial pembuat perahu, begitu juga motif tikar menunjukkan keahlian tertentu yang dimiliki kelompok sosial tertentu dalam masyarakat Gowa (lihat lampiran foto 2 dan foto 3 ).

Motif fauna, baik berupa gambar utuh, naga berkaki, ular, lipan dan ikan (lihat lampiran foto 3). Maupun berupa jejak kaki binatang yaitu ayam, anjing dan kuda. Menurut Muhlis Paeni; Menyebutkan bahwa fauna itu salah satu binatang yang diperkirakan digunakan sebagai tumbal, inilah salah satunya bekas kaki yang diinjakkan pada batu bata untuk sebagai bukti dalam upacara setelah pemasangan bata pada dinding Somba Opu.

Motif tulisan, huruf lontara kuno jangangjangang (lontara awal) yang terbaca "Appala Ngagappa Appinyawa Batara”. Artinya: Kumohon mendapat restu dari Dewata, petunjuk dari Dewa (lihat lampiran foto 5).

Motif pertanggalan (kotika), kotika merupakan kalender untuk menentukan hari-hari baik dan hari-hari buruk untuk memulai kegiatan atau usaha (lihat lampiran foto 6).

Motif-motif tak beraturan pada bata Benteng Somba Opu (belum teridentifikasi). Kemungkinan merupakan lambang atau simbol tertentu.

Motif Naga berkaki, kemungkinan tanda awal keberadaan orang Cina di Gowa.

Pola hias tersebut di atas merupakan suatu simbol yang mempunyai arti dan makna khusus, tidak hanya sebagai hiasan belaka, akan tetapi memiliki latar belakang sejarah yang berkaitan dengan kebutuhan lain, diantaranya: Apakah sebagai ritual dalam pelaksanaan mendirikan dinding benteng atau dalam hal makna tertentu.

Eksistensi pola hias, merupakan petunjuk adanya motif lokal yang jarang ditemukan menjadi buah imajinasi pembuatnya yang didasari oleh faktor lingkungan dan sturuktur sosial masyarakat pada waktu itu. Kini belum pernah ditemukan dari sumber berita lokal dan berita dari Cina yang menjelaskan adanya arti dari temuan ini di Benteng Somba Opu. Hanya temuan pertanggalan seperti pada bata yaitu, goresan segi empat kemudian diberi tanda kali teknik gores dan titik-titik dengan teknik tusuk pada bata yang indikasi kotika (mengetahui hari-hari baik dan hari-hari buruk). Bentuk pola hias kotika ini sangat bermanfaat ketika dalam hal melakukan aktifitas sehari-hari agar memperoleh hasil yang memuaskan.

Pola hias binatang atau bekas kaki binatang mempunyai latar belakang tersendiri yang erat kaitannya dengan kehidupan manusia, baik secara sakral maupun profan. Van Der Hoop dalam bukunya yang berjudul; Ragam- ragam perhiasan Indonesia, bahwa di seluruh dunia, binatang itu artinya sebagai perlambang dan sebagai ragam perhiasan. Begitu juga di Indonesia ragam hias seperti burung atau binatang sering dijadikan lambang roh orang yang telah meninggal. Ayam jantan dihubungkan dengan matahari karena memperdengarkan suaranya sewaktu mata hari akan terbit. Selain itu ayam jantan juga melambangkan kekuatan, keberanian dan kesuburan. Ragam hias katak dihubungkan dengan ilmu sihir dan hujan sedangkan kadal diartikan sebagai penjelmaan dewa. (Van Der Hoop, 1949). Beberapa bata berhias yang telah disajikan dapat dikelompokkan dalam beberapa jenis fungsi dan makna tertentu.

\section{Fungsi Bata}

Beberapa kemungkinan yang menjadi faktor yang melatar belakangi adalah: Kepandaian membuat bata mempunyai fungsi utama bersifat teknis untuk bahan penyusun bangunan yang permanen. Sehubungan dengan hiasan bata baik dengan teknik gores, tera, maupun jejak dapat berfungsi, yaitu;

Fungsi utama adalah Penguat ikatan antara bata dengan bata lainnya, terutama untuk struktur dinding yang berspesi. Sebagaimana juga yang terdapat di daerah lain pada situs Biting (Medan), telah ditemukan bata-bata bergores/berhias. Dan bentuk-bentuk hiasan yang ada hampir sama dengan yang ditemukan di situs Benteng Somba Opu. Sebagian besar bata-bata dari situs Biting memiliki pola hias geometris. Bentuk semacam pohon, sulur, celurit, juga jejak kaki binatang (anjing dan ayam). fungsi yang ada bersifat teknis untuk memperkuat daya rekat antara satu bata dengan bata yang lain (Koestoro, 1988: 139-141) Diduga bata-bata berhias dari Benteng Somba Opu memiliki fungsi sama dengan yang ada di situs Biting. Kemungkinan bata yang dimaksud ditandai motif-motif yang relatif sederhana, karena mengingat fungsi utama 
bersifat teknis. Bentuk geometris, garis diagonal, cap tangan, bentuk yang tak beraturan merupakan bentuk-bentuk yang sesuai fungsi ini.

Fungsi lainnya, menggambarkan fungsi ekonomis. Bata tersebut bisa jadi merupakan barang dagangan. Penandaan yang ada kemungkinan berfungsimerekdagang atau dari produsen (pembuat bata). Bukti penjualan bata misalnya terjadi masa pemerintahan Sultan Agung di Kerajaan Mataram, Islam, bata pernah ditukarkan empat buah meriam. Bata tersebut diberi nilai 600 picis atau 14 Stuiver (bolongan) tiap seratus buahnya. Bata-bata tadi akan dipergunakan Belanda untuk membangun loji di Jepara (Sarjianto, 1995: 64). Untuk motif yang lain, bunga parenreng misalnya, meskipun dari segi konsep mengandung makna religi namun dari segi tujuan menunjukkan fungsi sosial ekonomi, karena bunga tersebut dimaksudkan untuk melancarkan usaha/rejeki. Motif kaki binatang, ayam, kuda, terkait erat dengan adanya usaha peternakan yang kemungkinan telah dikembangkan di lingkungan masyarakat Gowa saat itu.

Himpunan nilai kepercayaan pada fungsi bata-bata Benteng Somba Opu Sebagai simbol penolak bahaya. Untuk jenis binatang tertentu dianggap sebagai tumbal dalam pembuatan bata, tetapi mungkin lebih dari itu sebagai tumbal dalam pendirian bangunan benteng/kerajaan Gowa. Seperti data temuan bata berelief dari situs di Kelurahan Muliakerta, Desa Negeri Baru, Ketapang, Kalimantan Barat, yang merupakan situs bekas kerajaan Tanjungpura. Di situs tersebut ditemukan bata-bata dengan cap jari dengan jumlah yang banyak, ukurannya juga bervariasi. Hal yang menarik adalah adanya temuan bata berhiaskan bentuk kala. Temuan ini mengingatkan pada temuan bata dari situs Amuntai (Kalimantan Selatan) dari bekas reruntuhan candi. Bata-bata yang ada juga mempunyai kemiripan bentuk dengan bata dari Jawa Timur (Trowulan) dari abad ke XIV (Surachman, 1996: 3-4).

Kala dalam mitologi Hindu merupakan simbol penolak bala (bahaya) dan biasa diletakkan diatas pintu masuk candi baik di Jawa Tengah maupun di Jawa Timur. Pada bata dari situs benteng Somba Opu upaya menolak bahaya digambarkan dengan cap jari-jari.serta pengadaan tumbal hewan-hewan tertentu yang jejak kakinya diterakan pada bata (anjing, ayam, kuda). Didukung dengan ditemukannya bata dengan hiasan Kotika untuk menentukan hari baik dan buruk, yang menguatkan kaitan motif tersebar dengan aspek religi.
Lambang dasar religi tertentu, yang menggambarkan latar belakang religi suatu masyarakat terutama pendukung bangunan yang ada. Seperti terjadi di muara Jambi, Negeri Baru, dari data temuan kedua situs ini didukung data lain yang dapat diketahui pendukung budayanya berlatar belakang agama Hindu dan Budha. Untuk bata dari benteng Somba Opu unsur-unsur kepercayaan dari diluar kurang tampak, namun yang pasti mereka telah memiliki kepercayaan sendiri. Motif Kotika, bunga parenreng, kuda dan sebagainya menguatkan asumsi ini. Meskipun dalam batas-batas tertentu mungkin konsep yang ada mengadopsi dari anasir budaya lain. Perilaku motif-motif tertentu pada bata, jenis motif yang dituangkan (naga, anjing, ayam) memiliki kesamaan dengan situs-situs lain dari masa Hindu Budha (Biting, Amuntai, Negeri Baru, Jambi).

\section{PENUTUP}

Arkeologi bata benteng Somba Opu dan sumber sejarah, mengingatkan kita bahwa situs Benteng Somba Opu pernah jaya sekitar abad ke XVII Masehi, karena dalam kajian sejarah Kerajaan Gowa Tallo, bahwa proses kolonialisasi diawali dengan kegiatan perdagangan, penguasaan ekonomi kemudian meningkat menjadi penguasaan politik, dengan penguasaan inilah terjadi suatu tekanan dan akhirnya disepakati berdasarkan perjanjian Bungayya maka Benteng Somba Opu dihancurkan diratakan dengan tanah oleh Belanda, dari insiden hampir empat abad yang lalu ini masih dapat terungkap dan diidentifikasi data bata berhias yang terpendam di dalam tanah.

Tinggalan arkeologi berupa fragmen bata yang masih jelas goresan huruf dan hiasan menguraikan versus pendapat yang mengungkap bahwa motif-motif yang ada sebagai hasil industri, kemudian makna indikasi religi, atau sarana aktifitas perdagangan. Pendapat ini ada kemungkinan benar, atau mungkin pula ada pengertian lain, karena yang tertera di permukaan bata tidak ada catatan tentang arti dari motif tersebut, kecuali aksara jangangjangang yang indikasi persembahan kepada Dewa "kumohon restu, petujuk dari maha pencipta" dan masih jelas tulisannya.

Eksistensi temuan arkeologi tersebut memperjelas keberadaan kerajaan Gowa di masa lalu, sebagai salah satu kerajaan di Sulawesi Selatan yang pernah memainkan peranan penting dalam kontak perdagangan secara global. Dengan demikian temuan arkeologi di wilayah Benteng Somba Opu 
dapat dijadikan sebagai sarana pemahaman kita tentang konsep pemerintahan secara terpusat di masa lalu atau sebagai benteng induk. Tentunya situs Benteng Somba Opu yang diakui sebagai tinggalan sejarah yang mempunyai nilai penting saat itu.

\section{UCAPAN TERIMA KASIH}

Tulisan ini dapat selesai atas bantuan banyak pihak. penulis menyampaikan terima kasih kepada Kepala Balai Arkeologi Makassar yang telah menugaskan penulis dalam penelitian ini, juga saya sampikan ucapan terima kasih kepada para informan yang telah membantu selama penelitian ini dilakukan dan terakhir kepada redaksi jurnal AlQalam yang bersedia memuat tulisan ini

\section{DAFTAR PUSTAKA}

Bernadeta, 2009. "Tradisi Megalitik Dalam Ranah Pemahaman Sacral dan Profan di situs Lawo, Soppeng", WalennaE. Volume 12 No.1 hal. 11- 37.

Binford R Lewis, 1965 "Archaeology as archaeology" American Antiquity, No 28 1965, 217-225

Darmawan MR, Muslimin A.R. Efendy, M. Ramli, 1990. Klenteng Ibu Agung Bahari Ujung Pandang. Yayasan Vihara Ibu Agung Bahari.

Darmawan, dkk. 1992. "Museum Karaeng Pattingalloang". Ujung Pandang Suaka Peninggalan Sejarah dan Purbakala.

Departemen Kebudayaan dan Pariwisata . 2006. Pedoman Pengelolaan Direktorat Museum Direktorat Jenderal Sejarah dan Purbakala Departemen Kebudayaan dan Pariwisata.

Hoop, A. N. J. Th. a Th.Van der. 1949. Ragam-ragam Perhiasan Indonesia. Bandung, A. C. Nix \& Co.

Lucas, Partanda Koestoro. 1988. "Analisis Data Bangunan Dari Situs Biting", Jakarta. REHPA III, Depdikbud, Jakarta: 1988.

Muhaeminah, 2013. LP. Jejak-jejak Arkeologi Islam di Wilayah Kerajaan Gowa. Makassr. Balai Arkeologi, (belum terbit).

Muhaeminah. 2009. "Benteng Kolonial Belanda di Balanipa kabupaten Sinjai” : WalennaE Volume 11 Nomor 1 hal51-64 Poelinggomang, E. L, Suriadi Mappangara, Daud Limbugau, Syahrul Amal, dan Sahajuddin. (2004).
Sejarah Sulawesi Selatan Jilid 1. Makassar: Badan Penelitian dan Pengembangan Daerah (Balitbangda).

Poelinggomang, E. L, Suriadi Mappangara, dkk. 2004.. Sejarah Sulawesi Selatan Jilid 1. Makassar: Badan Penelitian dan Pengembangan Daerah (Balitbangda).

Pradadimara, Dias. 2013." Benteng dan Perkembangan Kota" : Dari Kale Gowa ke Somba Opu, Merajut Simpul-Simpul Pertahanan Kerajaan Gowa di Sulawesi Selatan. Makassar: Balai Pelestarian Cagar Budaya Makassar atas kerjasama dengan Penerbit Identitas Unhas dan Danarosi Madia.

Rosmawati. 2013. "Perkembangan Tamadun Islam di Sulawesi Selatan, Indonesia dari Perspektif Arkeologi dan Sejarah", Tesis Yang di Serahkan Untuk Memenuhi Keperluan Bagi Ijasah Doktor Falsafah. Universitas Sains Malaysia.

Rustan, Iswadi danSupriadi, 2013.'Konservasi dan Zonasi Benteng Somba Opu". Dari Kale Gowa ke Somba Opu, Merajut Simpu-simpul Pertahanan Kerajaan Gowa di Sulawesi Selatan. Makassar. Balai Pelestarian Cagar Budaya Makassar atas kerjasama dengan Penerbit Identitas Unhas Danarosi Media.

Sarjianto, 1995. 'Sistem Perekonomian Kota(Koleksi Museum Karaeng Pattingalloang). Dalam Naditira Widya No. 03/1999. Banjarbaru: Balai Arkeologi Banjarmasin.

Soeroto, Myrtha. 2003. Dari Arsitektur Tradional Menuju Arsitektur Indonesia. Jakarta. Galia Indonesia.

Sumalyo, Yulianto. 2013. Arsitektur, "Konstruksi dan Pola Pemukiman dalam Benteng”. Dari Kale Gowa ke Somba Opu: Merajut Simpulsimpul Pertahanan Kerajaan Gowa di Sulawesi Selatan. Makassar. Balai Pelestarian Cagar Budaya Makassar atas kerjasama dengan Penerbit Identitas Unhas dan Danarosi Media.

Surachman, Heddy. 1996. "Perdagangan Kuna di Ketapang (Suatu Kajian awal)”, Ujung Pandang. Makalah EHPA

Tim Penelitian, 2007. LP” Peradaban Gowa-Tallo Tahap I". Jakarta. Pusat Penelitian Arkeologi Nasional 


\section{Lampiran:}

Fhoto 1 Motif perahu

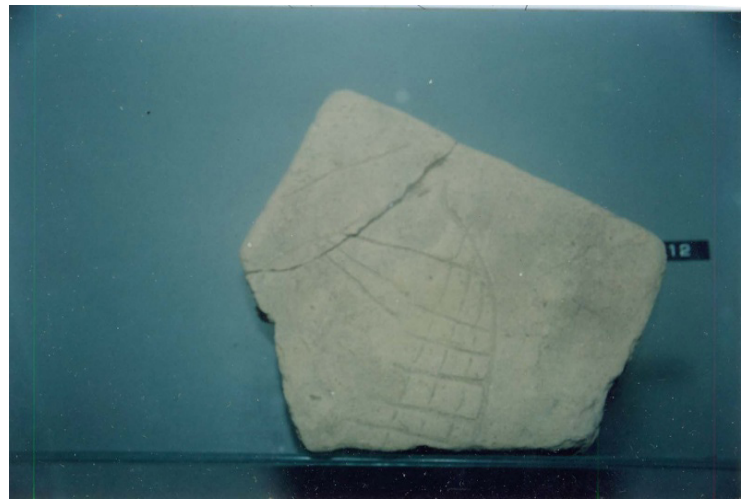

Foto 2: Fragmen bata motif mata hari hasil ekskavasi di Barombong 2013

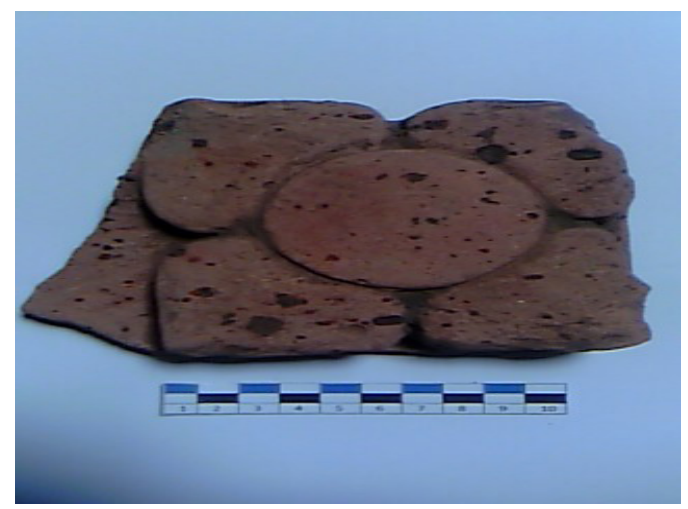

Foto 3: Motif flora yang sering ditemukan pada bangunan kuno di Sulawesi Selatan (Sumber Ibu Rosmawati 2013:574)

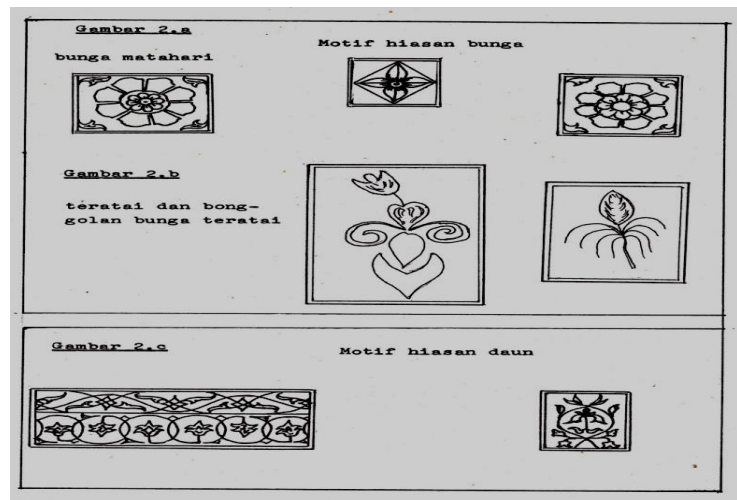


Foto 4: Bekas kaki anjing dan ayam pada bata Benteng Somba Opu
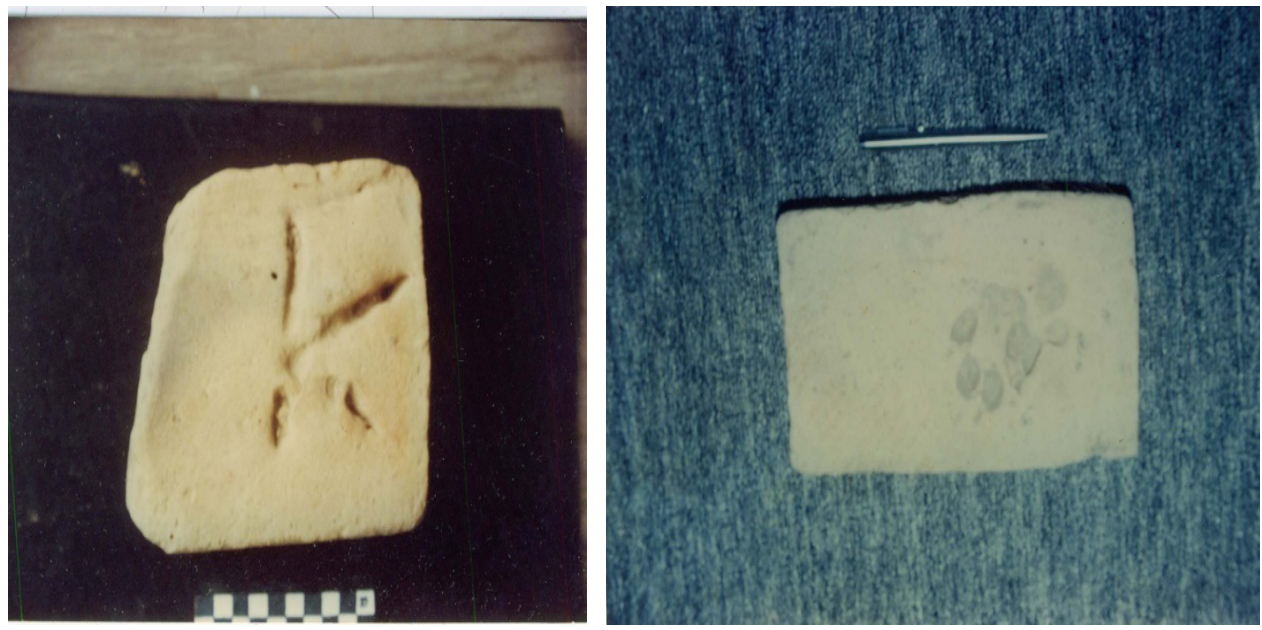

Foto 5: Aksara Kuno Gowa (jangang-jangang)
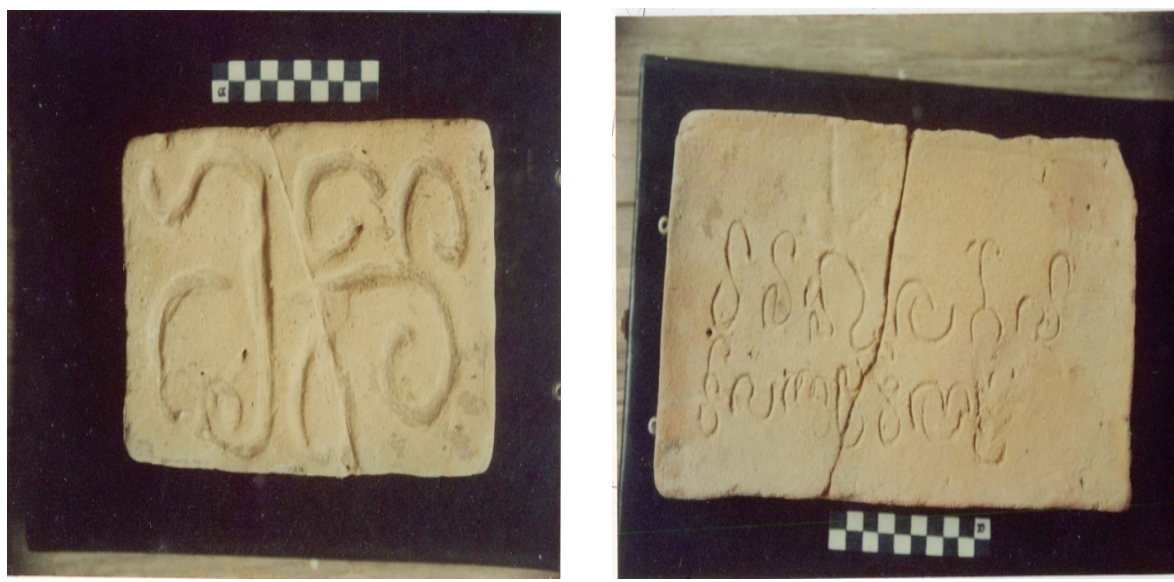

Fhoto 6. kotika
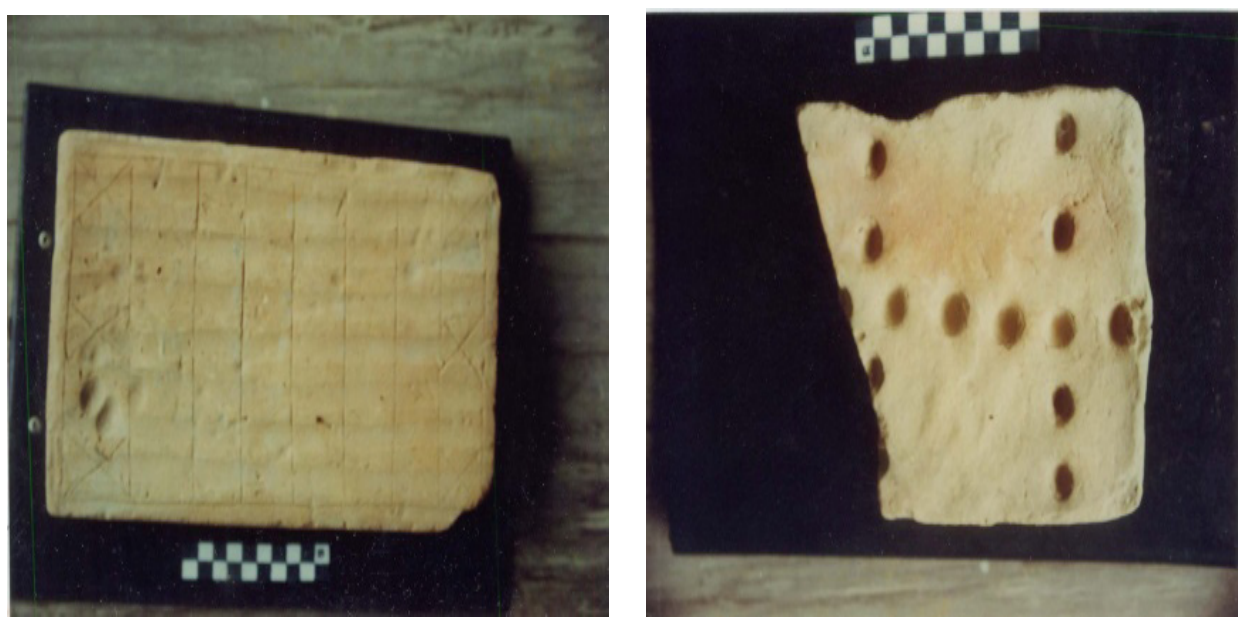
Foto 7. Motif tikar

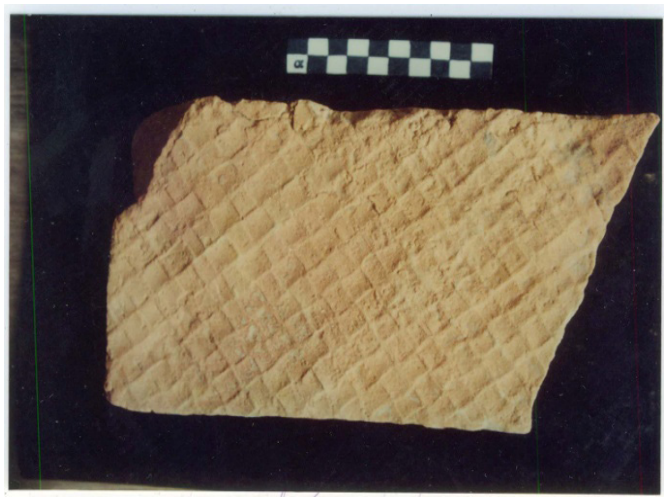

